\title{
Hazards and critical control points in Brazilian seafood dish preparation
}

\author{
Celina M.P.A. Landeiro ${ }^{a}$, Rogeria C.C. Almeida ${ }^{a, *}$, Ana T.M. Nascimento ${ }^{a}$, \\ Jeane S. Ferreira ${ }^{a}$, Tomomasa Yano ${ }^{b}$, Paulo F. Almeida ${ }^{c}$ \\ ${ }^{\text {a }}$ Departamento de Ciência dos Alimentos da Escola de Nutrição, Universidade Federal da Bahia, Av. Paulo VI, No. 2174/303, Itaigara, \\ CEP.: 41810-001, Salvador, BA, Brazil \\ ${ }^{\mathrm{b}}$ Instituto de Biologia, Universidade Estadual de Campinas, Barão Geraldo, CEP 13100, Campinas, SP, Brazil \\ ${ }^{\mathrm{c}}$ Departamento de Ciências da Biointeração do Instituto de Ciências da Saúde, Universidade Federal da Bahia, Av. Reitor Miguel Calmon, s/n., Canela, \\ CEP.: 40110-160, Salvador, BA, Brazil
}

Received 29 August 2005; received in revised form 21 December 2005; accepted 23 December 2005

\begin{abstract}
There are many concerns about the sanitation practices used in the preparation of the foods and the occurrence of the gastrointestinal illness affecting mainly tourists who come to Salvador, Bahia, Brazil, on vacation is common. This paper describes the hazard analysis carried out on the manufacture of four seafood dishes at a traditional restaurant in the city of Salvador. These analyses consisted of detailed studies of the manufacture process of "moqueca de peixe", "bobó de camarão", "mariscada" and "casquinha de siri". The seafood dishes were usually cooked at temperatures that should have killed vegetative forms of food-borne pathogens. Hazards on CCPs were primarily associated to high counts of staphylococci TNase-coagulase positives mainly in "casquinha de siri" read to eat, held for $15 \mathrm{~h}$ before distribution, and detection of Escherichia coli strain producing cytotoxic necrosing factor type 1 on hands of food handlers. The control measures and monitoring procedures for seafood dish preparation are suggested.
\end{abstract}

(c) 2006 Elsevier Ltd. All rights reserved.

Keywords: Hazards; Brazilian seafood dishes; Food safety

\section{Introduction}

Tourism in Bahia, Brazil, represents one of the most important elements in its social and economic life. Varieties of "quitutes" or traditional foods form an integral part of the socio-cultural mix that characterizes tourism to the state and enhances its attraction. These traditional foods, are mostly African in origin, are made with fish, shellfish, red palm oil, coconut milk and spices.

Food safety is fundamental in food service because of the high numbers of meals served every day. Food-borne outbreaks resulting from such mass restaurant facilities have been reported worldwide. In the state of Bahia, 67,376 people reporting symptoms of febrile illness and

\footnotetext{
* Corresponding author. Tel.: +55 71 32637732; fax: +55 7132637704 . E-mail address: rogeriac@ufba.br (R.C.C. Almeida).
}

gastro enteric disease, associated with restaurant and street feeding in most of the cases, were admitted to hospital in 2000. This number represents a mean index of 515.49 cases per 100,000 inhabitants. That year Bahia was the state that spent the most on hospital admittance, $\mathrm{R} \$ 12,724,109.57$, representing $3.89 \%$ of the total spent on hospital admittance in the whole state (BRASIL, 2004).

In recent years, the HACCP concept has been proposed as the best approach to assure food safety. By identifying the critical control points (CCPs), industries, foodservice industry and enforcement authorities have more evidence on which to devise control measures, train staff and inform consumers (Panisello, Rooney, Quantick, \& StanwellSmith, 2000).

In designing the Hazard Analysis and Critical Control Points (HACCP) System in foodservice, one of the most important facts to be concerned with is the proper selection of verification parameters which must warrant the maximum 
information about control procedures at each and every one of the phases of the production line (ICMSF, 1988). Time and temperature and investigation of the counts of indicator microorganisms such as aerobic mesophilic bacteria, faecal coliform/Escherichia coli have been used to monitor the presence of pathogens in foods.

The focus of this study was to identify and monitor the CCPs in the preparation of four seafood dishes at a traditional restaurant in Salvador, Bahia, Brazil, to assure the safety of meals served to consumers and to contribute to the improvement of local social and economic life.

\section{Materials and methods}

\subsection{Hazard analysis and identification of critical control points}

A traditional restaurant located in Salvador cooperated in this study. The preparation of the traditional dishes include ingredients such as seafood, red palm oil, coconut milk and spices, and this particular restaurant processed approximately 1000 meals daily at high season mainly for tourists.

In this study, the following seafood dishes were selected for investigation: "moqueca de peixe" (fish, palm oil, coconut milk, tomato and seasoning), "casquinha de siri" (crab meat, palm oil and seasoning), "mariscada" (lobster, crab, shrimp, crawfish, mussel, squid, octopus, palm oil, coconut milk, tomato and seasoning) and "bobó de camarão" (shrimp, ground cassava, palm oil, coconut milk and seasoning).

Flow diagrams of the preparation of each seafood dishes were constructed in order to provide a clear, simple description of the steps involved in the process at the restaurant (ICMSF, 1988).

The identification of hazards was carried out according to International Commission on Microbiological Specification for Foods (ICMSF, 1988), by examining the characteristics of the raw seafood and ingredients and evaluating the variables that could influence the safety of food. Microbiological criteria were used to develop a preliminary HACCP system.

To determine CCPs, the decision tree described by ONU/OMS (1991) was used.

Samples of food were taken at each CCP and subsequently tested for total aerobic mesophilic bacteria (APC), the most probable number (MPN) of coliform/ E. coli, TNase-coagulase-positive staphylococci counts and the presence of Vibrio parahaemolyticus. The analysis also included measuring temperature immediately after reception, pre-preparation, preparation, cooking and holding stages. The thermometer was washed, cleaned with $70 \%$ alcohol three times and dried before inserting into the product.

Samples of hands of food handlers were taken immediately before the work time and evaluated for APC, coliform/E. coli and TNase-coagulase-positive staphylococci.
Samples of utensil were taken before use and tested for APC and samples of environment air were taken in prepreparation, cooking and distribution areas and tested for APC too.

\subsection{Sampling procedures}

During the study, six visits were made to the restaurant between July and September 2001. Sixty food samples, 18 utensil samples, 12 worker handling samples and 24 environmental samples were taken.

Separate triplicate 100 -g composite samples of all foods were aseptically collected in sterile plastic specimen bags at each stage previously identified as CCP (Messer, Midura, \& Peeler, 1992). Samples obtained from seafood including raw fish and raw shellfish received in the restaurant, fish and shellfish after the pre-preparation (defrosted at room temperature or tap water, washing and cleaning, addition of lemon juice, shared in portions of $5 \mathrm{~kg}$, addition of seasonings and freezing), preparation (defrosted and refrigeration) and cooking stages. Samples of the "casquinha de siri" dish when ready to eat were collected after the stage of holding too.

The samples of utensils including the aluminum cooking pot, aluminum skimmer and stainless steel tray were collected using the sponge method (Sveum, Moberg, Rude, \& Frank, 1992).

Samples were taken from the hands of food handlers who work in the pre-preparation, preparation and cooking areas and were also collected by polyurethane sponge.

Environmental air from pre-preparation, preparation and cooking areas was collected using the sedimentation method (Messer et al., 1992).

All samples collected were held in ice pack and taken to the laboratory within $4 \mathrm{~h}$ of collection for analysis.

\subsection{Laboratory procedures}

\subsubsection{Isolation and identification of microorganisms}

Sponges were previously tested for inhibitory properties (Daley, Pagotto, \& Farber, 1995).

One hundred $\mathrm{ml}$ of $0.1 \%$ peptone water with $0.5 \%$ sodium thiosulphate were added to the bags to homogenize the sponges (Sveum et al., 1992).

For the food samples, $25 \mathrm{~g}$ were blended with $225 \mathrm{ml}$ $0.1 \%$ peptone water and decimal dilutions were prepared (Messer et al., 1992).

Total aerobic plate count (APC) was carried out according to Stevenson and Segner (1992). Faecal coliforms were investigated by Most Probable Number (MPN) technique, using three tubes, according to Hitchins, Hartman, and Todd (1992). Tube showing gas production in EC broth was streaking on eosin methylene blue (EMB) agar to investigate the presence of $E$. coli. Colonies on EMB plates appearing bluish with greenish metallic sheen, which are characteristic of $E$. coli, were confirmed by biochemical tests of IMViC. PCR assay was carried out to verify the 
patogenicity of strains isolated (Blanco et al., 1997). Staphylococcal coagulase-positive were investigated according to Lancette and Tatini (1992) on Baird Parker agar supplemented with tellurite and egg yolk emulsion. TNase test was performed using DNase agar supplemented with agar, tris- $\mathrm{HCl}, o$-toluidine blue and calcium chloride (Bennett, Nortermans, \& Tatini, 1992). V. parahaemolyticus was investigated according to Kaisner, Tamplin, and Twedt (1992), using $50 \mathrm{~g}$ of foods homogenized with $450 \mathrm{ml}$ of tryptic soy broth (TSB) with $3.0 \% \mathrm{NaCl}$ for pre-enrichment, the horie arabinose ethyl violet broth (HAEB) for enrichment and the thiosulphate citrate bile sucrose (TCBS) agar with $3.0 \% \mathrm{NaCl}$ for isolation. Confirmation of $V$. parahaemolyticus was carried out by inoculating typical colonies into triple sugar iron (TSI) agar, growth on tryptic soy broth (TSB) containing $3 \% \mathrm{NaCl}$ at $42{ }^{\circ} \mathrm{C}$, halophilism in TSB with $0 \%, 6 \%, 8 \%$ and $10 \% \mathrm{NaCl}$, motility in sulfite indol medium (SIM) and oxidation/fermentation carbohydrates (sucrose, maltose, celobiose, trehalose, mannitol, dextrose and lactose).

All cultures were incubated at $37^{\circ} \mathrm{C}$ for $24-48 \mathrm{~h}$ except for coliform organism which was incubated at $37^{\circ} \mathrm{C}$ and $44{ }^{\circ} \mathrm{C}$ for $24 \mathrm{~h}$.

\subsubsection{PCR assay for E. coli strains}

Sample preparation. The PCR assay was performed using 20 (twenty) strains of $E$. coli isolated in this study. Bacterial cells in brain heart infusion (BHI) broth were pelleted at $12,000 \times g$ for $2 \mathrm{~min}$ and treated with lysozyme $(10 \mathrm{mg} / \mathrm{ml})$ and RNase $(10 \mathrm{mg} / \mathrm{ml})$. Crude cells lysates were treated with sodium duodecyl sulphate (SDS) and proteinase $\mathrm{K}(70 \mu \mathrm{l}$ of SDS $10 \%+5 \mu \mathrm{l}$ of proteinase $\mathrm{K}-10 \mathrm{mg}$ / $\mathrm{ml}$ ) and incubated at $65^{\circ} \mathrm{C}$ for $10 \mathrm{~min}$. DNA was extracted with $750 \mu$ of chloroform-isoamyl alcohol solution (24:1).

PCR assay. Table 1 shows the oligonucleotide primers used for PCR analyses. For amplification reactions, the most appropriate protocol was that described by Blanco et al. $(1997,1996)$, with some modifications suggested by Innis, Gelfand, Sninsky, and White (1990). In this way, for a total volume of $50 \mu \mathrm{l}$, the following was used: $5 \mu \mathrm{l}$ of buffer $10 \times(200 \mathrm{mM}$ tris $-\mathrm{HCl}-\mathrm{pH} \quad 8.0 ; 500 \mathrm{mM}$ de $\mathrm{KCl}) ; 3 \mu \mathrm{l}$ of $\mathrm{MgCl}_{2}(1.5 \mathrm{mM}) ; 1 \mu \mathrm{l}$ of dNTPs $(50 \mu \mathrm{M}$ of each one); $1 \mu \mathrm{l}$ of each primer ( $20 \mathrm{pmol}$ of each one); $2 \mu \mathrm{l}$ of DNA extracted (total DNA) (50-200 ng); $1 \mathrm{U}$ of Taq DNA polymerase enzyme (Gibco-Life Technologies) at concentration of $0.5 \mathrm{U}$ to $\mu$; Milli-Q water sterilized $(50 \mu 1)$.

The samples were amplified after an initial step of heating at $94{ }^{\circ} \mathrm{C} / 10 \mathrm{~min}$. The temperature was maintained at $60{ }^{\circ} \mathrm{C}$ until the addition of enzyme and after that 30 cycles in Termocycle GeneAmp PCR System 9700 were performed: $1 \mathrm{~min}$ at $94{ }^{\circ} \mathrm{C}$ (denaturing step); $1 \mathrm{~min}$ at indicate temperature for each primer (annealing step); $2 \mathrm{~min}$ at $72{ }^{\circ} \mathrm{C}$ (extension step). The reactions stayed at $72^{\circ} \mathrm{C}$ for 10 more minutes for final extension.

PCR products were fractionated by electrophoresis on $2 \%$ agarose gels, stained with ethidium bromide, and photographed under UV light. Molecular marker of 100$1500 \mathrm{~kb}$ (100 pb DNA Ladder - Promega) was used as a size standard.

\subsubsection{Analysis of data}

Counts of bacteria recovered from products were $\mathrm{cfu} \mathrm{cm}^{-2}$ for aerobes recovered from utensil surfaces; $\mathrm{cfu} \mathrm{g}^{-1}$ for aerobes and staphylococcal, and MPN g ${ }^{-1}$ for coliform and E. coli recovered from foods; and cfu hand ${ }^{-1}$ for aerobes and staphylococcal, and MPN hand ${ }^{-1}$ for coliform and E. coli recovered from hands. Counts of bacteria recovered from environmental air were $\mathrm{cfu} / \mathrm{cm}^{2} /$ week. The analyses were performed in three times and all such bacterial counts in colony forming units or most probable number were transformed into log values. Values of the mean $\log (\bar{X})$ of the set of bacterial counts were calculated. In the calculation of $\bar{X}$ for staphylococcal count and coliform/E. coli estimative from sponge samples, a log values of zero was assumed as the count for each sample in which the bacteria were not detected $(<10 ;<1.5)$. For samples of foods, $\log$ values of zero were assumed for samples in which staphylococcal were not detected $\left(<1 \mathrm{~g}^{-1}\right)$ and coliform $/ E$. coli were not enumerated $\left(<0.5 \mathrm{~g}^{-1}\right)$.

Table 1

Oligonucleotide primers used in the evaluation of the patogenicity of $E$. coli isolates

\begin{tabular}{|c|c|c|c|c|}
\hline Primer toxins & Sequence & T.A. ${ }^{\mathrm{a}}\left({ }^{\circ} \mathrm{C}\right)$ & P.A. $^{\text {b }}(\mathrm{bp})$ & Reference \\
\hline ST-I & $\begin{array}{l}\text { 5'-TCCGTGAAACAACATGACGG-3' } \\
\text { 5'-ATAACATCCAGCACAGGCAG-3' }\end{array}$ & 60 & 244 & So and McCarty (1980) \\
\hline CNFs & $\begin{array}{l}\text { 5'-CTGGAGTCGAGGTGGTGG-3' } \\
5^{\prime} \text {-CTCCTGTCAACCACAGCC-3' }\end{array}$ & 56 & 533 & Blanco et al. (1996) \\
\hline CNF-I & $\begin{array}{l}\text { 5'-GAACTTATTAAGGATAGT-3' } \\
\text { 5'-CATTATTTATAACGCTG-3' }^{\prime}\end{array}$ & 45 & 543 & Blanco et al. (1996) \\
\hline CNF-II & $\begin{array}{l}\text { 5'-AATCTAATTAAAGAGAAC-3' } \\
5^{\prime} \text {-CATGCTTTGTATATCTA-3' }\end{array}$ & 44 & 543 & Blanco et al. (1996) \\
\hline SLT-I & $\begin{array}{l}5^{\prime} \text {-AGGTTGCAGCTCTCTTTGAATA-3' } \\
5^{\prime} \text {-TGCAAACAAATTATCCCCTGAG-3' }\end{array}$ & 57 & 364 & Jackson et al. (1988) \\
\hline SLT-II & $\begin{array}{l}\text { 5'-GGGCAGTTATTTTGCTGTGGA-3' } \\
\text { 5'-GTATCTGCCTGAAGCGTAA-3' }^{\prime}\end{array}$ & 59 & 386 & Jackson et al. (1987) \\
\hline
\end{tabular}

\footnotetext{
${ }^{a}$ Annealing temperatures for each primer pair was calculated using the formula: T.A. $=4(\mathrm{G}+\mathrm{C})+2(\mathrm{~A}+\mathrm{T})(\mathrm{Ojeniyi}$ et al., 1994).

b Product amplified for each primer pair.
} 


\section{Results and discussion}

\subsection{Analysis of seafood dishes preparation CCPS}

Flowchart and critical control points for the preparation of Brazilian seafood dishes is presented in Fig. 1. It reveals that the seafood dishes were prepared using similar ingredients, fish and/or shellfish, coconut milk, palm oil, tomato and seasoning. In the preparation of "bobó de camarão" ground cassava was also an ingredient. The critical control points (CCPs) identified were the reception of raw fish and shellfish, pre-preparation, preparation, cooking and holding stages.

The fish and shellfish used for prepare the dishes were obtained from approved water under hygienic conditions, but after the reception in the restaurant the raw seafood remained at room temperature for more than $2 \mathrm{~h}$, then this stage was considered a CCP. Controls of time and temperature at this stage should be established and systematically monitored to prevent the creation of a microbiological hazard. The other stages, such as pre-preparation and preparation were considered critical control points because of the possibility of the introduction of pathogenic microorganisms such as Staphylococcus aureus or E. coli from hands of food handlers or utensils. Cooking is the only heat process for hot entree items in a cook/serve food service system and hence represents $100 \%$ of the processing requirement. Cooking must ensure that pathogenic microorganisms do not survive the process to reduce the risk to public health. The hot-holding stage was considered a CCP in the preparation of "casquinha de siri" because of the possibility of cross-contamination and the creation of a biological haz-

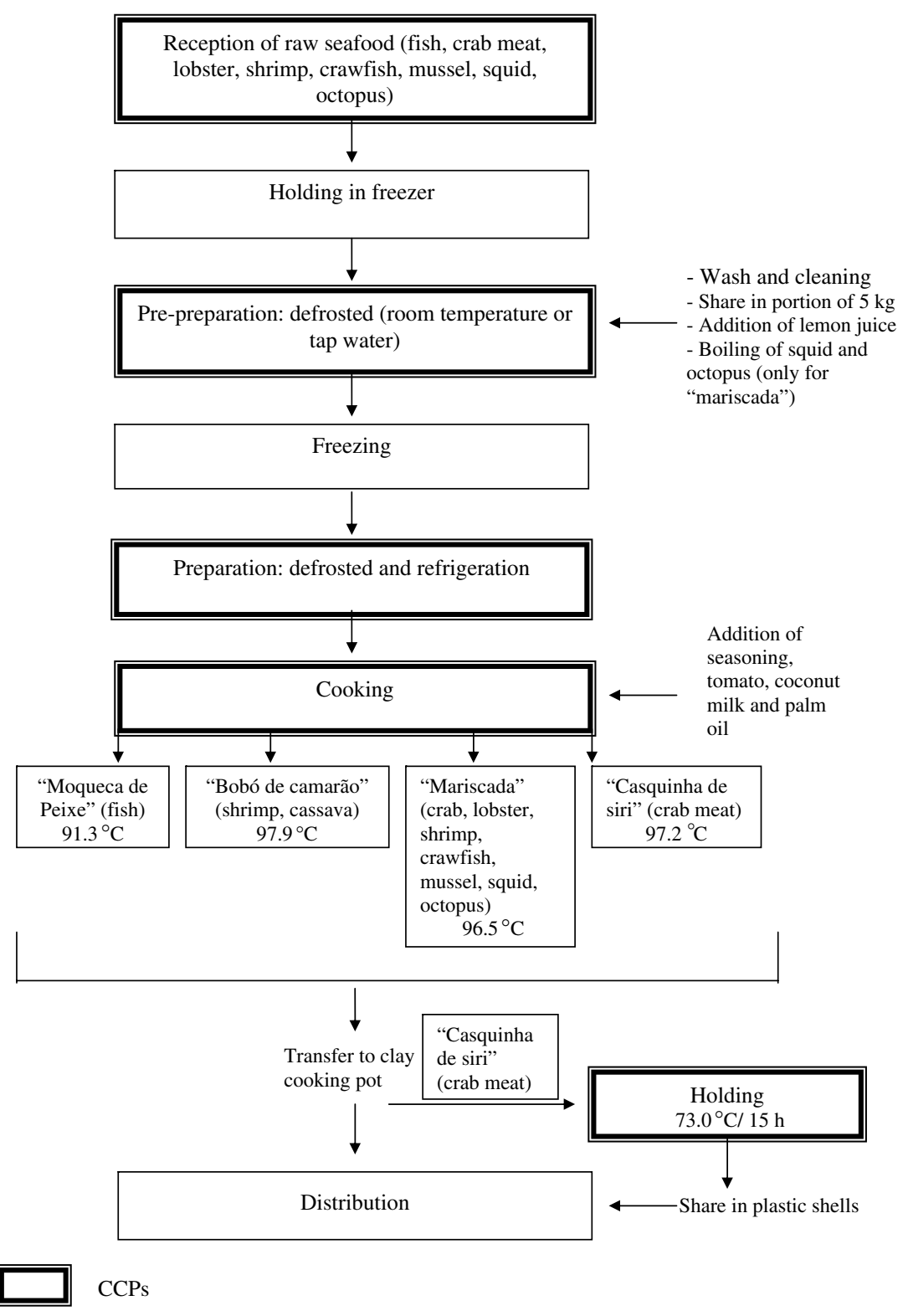

Fig. 1. Flow diagram of seafood dishes manufacturing and critical control points (CCPs). 
ard. Preventive measures at the cooking and hot-holding stages consisted of monitoring the temperature and time.

\subsection{Microbiological analysis of seafood dishes}

The microbiological conditions of raw fish and shellfish at the different stages of preparation of "moqueca de peixe", "mariscada", "bobó de camarão" and "casquinha de siri" dishes are demonstrated in Table 2.

After reception, the raw seafood was defrosted at room temperature $\left(27-34^{\circ} \mathrm{C}\right)$ or in tap water. The log mean numbers of aerobes recovered from raw fish samples after the reception stage in the manufacturing of "moqueca de peixe" dish were about $1.4 \log$ unit more than log mean numbers recovered after the pre-preparation, $0.5 \mathrm{log}$ unit more after the preparation and $1.6 \log$ unit more after the cooking stages. For staphylococcal TNase-coagulase positive, the log mean numbers recovered from raw fish after the reception stage were about $1.2 \log$ unit more than log mean numbers recovered after the pre-preparation and $3.1 \mathrm{log}$ units more after the cooking stage. After the preparation of the dish an increase in these counts was observed and the $\log$ mean numbers was 0.6 higher than that observed after the reception stage (Table 2). E. coli was recovered only from seafood after the preparation stage ( $0.9 \log$ MPN/g) where the Most Probable Number of coliforms was higher, about $2.7 \log$ MPN/g. After the cooking, the microorganism group was not detected in food samples $(<0.5 \log$ MPN/g) (Table 2). V. parahaemolyticus was not isolated from the food samples.
The dish was usually cooked at temperature that should have killed vegetative forms of food-borne pathogens and the isolation of Staphylococcus TNase-coagulase positive is attributed to post-processing contamination from food handlers (Table 2).

In the investigation of "bobó de camarão" the counts of microorganisms aerobes recovered from samples after the reception of shrimp were lower than that observed after the other stages, except for the food when ready to eat. Staphylococcal counts were higher after the reception of shrimp, and a reduction of $2.3 \log$ units was observed in samples from food ready to eat (Table 2).

The counts of aerobes from the samples of seafood after the reception stage in the preparation of "mariscada" and "casquinha de siri" were lower than those found in the raw fish used in the manufacturing of "moqueca de peixe" (Table 2). However, relatively poor microbiological conditions of the raw foods after the stages of pre-preparation ("casquinha de siri") and preparation ("casquinha de siri" and "mariscada) were found. Despite the presence of faecal coliform, E. coli was not isolated from the samples of "casquinha de siri". In samples of "mariscada", E. coli was isolated at all stages, exception in food which was ready to eat, and $V$. parahaemolyticus was isolated in samples taken after the preparation of the dish (Table 2). The presence of $V$. parahaemolyticus in "mariscada" after the preparation stage could be attributed to occurrence of cross-contamination in the refrigerator, considering that the seafood and ingredients stayed there for long time (up to seven days) before cooking.

Table 2

Bacterial counts in log cycles and temperature values ${ }^{\mathrm{a}}$ at the various stages of the preparation of seafood dishes

\begin{tabular}{|c|c|c|c|c|}
\hline Procedure/period of sampling & "Moqueca de peixe" & "Bobó de camarão" & "Mariscada" & "Casquinha de siri" \\
\hline After reception $\left({ }^{\circ} \mathrm{C}\right)$ & $-10.6 \pm 1.4$ & $-10.3 \pm 0.8$ & $-10.1 \pm 1.4$ & $-12.8 \pm 2.0$ \\
\hline Aerobes & 7.1 & 5.0 & 5.9 & 4.3 \\
\hline Staphylococcal & 5.6 & 6.8 & 5.0 & 6.8 \\
\hline Coliform/E.coli & $1.7 /<0.5$ & $0.0 /<0.5$ & $2.7 / 0.5$ & $1.5 /<0.5$ \\
\hline Vibrio parahaemolyticus & ni & ni & ni & ni \\
\hline After pre-preparation $\left({ }^{\circ} \mathrm{C}\right)$ & $-12.1 \pm 1.0$ & $-9.5 \pm 1.6$ & $-11.2 \pm 1.0$ & $-13.1 \pm 1.1$ \\
\hline Aerobes & 5.7 & 6.4 & 5.8 & 7.6 \\
\hline Staphylococcal & 4.4 & 4.0 & 6.2 & 6.6 \\
\hline Coliform/E. coli & $1.7 /<0.5$ & $1.7 /<0.5$ & $2.6 / 1.3$ & $1.4 /<0.5$ \\
\hline Vibrio parahaemolyticus & $\mathrm{ni}$ & $\mathrm{ni}$ & $\mathrm{ni}$ & $\mathrm{ni}$ \\
\hline After preparation $\left({ }^{\circ} \mathrm{C}\right)$ & $2.2 \pm 0.8$ & $-0.3 \pm 5.5$ & $2.8 \pm 1.2$ & $2.7 \pm 1.9$ \\
\hline Aerobes & 6.6 & 6.4 & 8.1 & 7.9 \\
\hline Staphylococcal & 6.2 & 4.0 & 5.6 & 6.8 \\
\hline Coliform/E. coli & $2.7 / 0.9$ & $1.7 /<0.5$ & 1.0 to $\geqslant 3.0 / 1.7$ & $2.3 /<0.5$ \\
\hline Vibrio parahaemolyticus & ni & ni & positive & $\mathrm{ni}$ \\
\hline After cooking $\left({ }^{\circ} \mathrm{C}\right)$ & $91.3 \pm 1.4$ & $97.9 \pm 0.9$ & $96.5 \pm 1.4$ & $73.0 \pm 6.9^{\mathrm{b}}$ \\
\hline Aerobes & 5.5 & 4.3 & 5.3 & 3.9 \\
\hline Staphylococcal & 2.5 & 4.5 & 4.5 & 6.7 \\
\hline Coliform/E. coli & $<0.5 /<0.5$ & $1.3 /<0.5$ & $<0.5 /<0.5$ & $<0.5 /<0.5$ \\
\hline Vibrio parahaemolyticus & ni & ni & ni & ni \\
\hline
\end{tabular}

ni-not isolated; \pm Standard deviation.

${ }^{a}$ Mean of three observations.

b Holding stage. 
Results from PCR assay showed that the strains of $E$. coli isolated from samples of fish used in the manufacturing of "moqueca de peixe" dish were not pathogenic. The strains isolated from shellfish used in the manufacturing of "mariscada" taken after the preparation stage was not a producer of SLT-I or SLT-II and ST-I toxins, but some of them showed the presence of the gene for cytotoxic necrotizing factor 1 , CNF-I (Table 4).

Certain E. coli strains that produce a toxin-like protein designated cytotoxic necrotizing factor 1 (CNF1) have been shown to be associated mainly with urinary tract infections or, more rarely, with gastroenteritis. CNF1 is a chromosomally encoded uropathogenic $E$. coli toxin that catalyzes the deamidation of the small GTPases RhoA, Rhac, and Cdc42 (Brest et al., 2004) and affects a variety of cellular functions in vitro, presumably through activation of the Rho GTPases (Meysick, Mills, \& O'Brien, 2001).

The high contamination of dishes observed mainly after the preparation stage indicated that the early stage of prepreparation is a CCP that needed effective control and that refrigeration (up to seven days) should be reduced to assure the control of a biological hazard.

\subsection{Microbiological analysis of hands, utensils and environmental air}

The microbiological conditions of hands, utensils and ambient air are demonstrated in Table 3.

In general, microbial samples collected from workers' hands during the manufacturing of seafood dishes presented high aerobic plate and staphylococcal mean counts (Table 3).

In restaurants foods are more likely than drinks to contain $S$. aureus because of repeated hand contact. According to Soriano, Font, Moltó, and Mañes (2002) staphylococcal food poisoning results from the consumption of a food in which enterotoxigenic staphylococci have grown and formed enterotoxin(s). Recognition of the sources of transmission and outbreaks of enterotoxigenic staphylococci are important to prevent this type of food poisoning.

Another pathogen isolated from the samples was E. coli. It is also a significant cause of food poisoning. PCR assay showed that the hand of the food handler in the cooking area, known as hand B, was contaminated by E. coli strain producer of cytotoxic necrosing factor type 1, CNF-I (Table 4). The presence of E. coli on hands emphasizes significant fecal contamination, and indicates that food handlers were not taking enough care in hand hygiene (Aiçiçek, Aydogan, Kuçukkaraaslan, Baysallar, \& Basustaoglu, 2004).

On investigation of utensils, the aluminum cooking pot showed the highest aerobic plate counts (Table 3). The fact that all utensil surfaces exhibited some degree of bacterial contamination illustrates the potential of cross-contamination of surfaces due to the handling of foods and subsequent normal usage of the restaurant. According to standards suggested by Solberg et al. (1990), the utensils investigated were not safe for contact with foods.

The samples from environmental air showed higher aerobic plate counts than those suggested by Sveum et al. (1992), $1.48 \log \mathrm{cfu} / \mathrm{cm}^{2} /$ week (Table 3). Therefore, it is important to note that holding the dish "casquinha de siri" for $15 \mathrm{~h}$ could be a risk, because the dish was not covered.

In general, food preparation and handling abuse was a characteristic of the restaurant and the data presented here has highlighted the potential food safety hazards in the preparation of all four dishes. The microbiological conditions of dishes were similar, such as those observed on hands and utensils. Thus, it is apparent that the microbiological conditions of the dishes are determined by the way the processes are implemented, and not by the type or condition of the incoming stock. These results indicated that restaurant staff needed to improve personal hygiene practices and educational programs should be established to continually reinforce food-safety principles. Short courses,

Table 3

Bacterial counts on hands, utensils and ambient air in the preparation of seafood dishes

\begin{tabular}{|c|c|c|c|}
\hline Samples & Aerobes & Staphylococcal & Coliform/E. coli \\
\hline \multicolumn{4}{|l|}{ Hands $(\log C F U, \log M P N / \text { hand })^{\mathrm{a}}$} \\
\hline Food handlers in pre-preparation and preparation areas & 6.5 & 7.4 & $2.6 / 1.9$ \\
\hline Food handlers in cooking area & 7.0 & 6.9 & $3.3 / 1.8$ \\
\hline \multicolumn{4}{|l|}{ Utensils $(\log C F U / \mathrm{cm})^{2 \mathrm{a}}$} \\
\hline Stainless steel tray & 3.5 & - & - \\
\hline Aluminum cooking pot & 3.7 & - & - \\
\hline Aluminum skimmers & 2.9 & - & - \\
\hline Pre-preparation and preparation areas & 2.8 & - & - \\
\hline Cooking area & 2.8 & - & - \\
\hline Distribution area & 2.8 & - & - \\
\hline
\end{tabular}

- not determined.

${ }^{\text {a }}$ Mean log of three observations. 
Table 4

Investigation of Escherichia coli strains for patogenicity

\begin{tabular}{|c|c|c|c|}
\hline Source & CNFs & ST-I & LST-I, LST-II \\
\hline Hand $\mathrm{A}$-pre-preparation and preparation areas & Negative & Negative & Negative \\
\hline Hand B - cooking area & Negative & Negative & Negative \\
\hline Hand $\mathrm{B}$ - cooking area & CNF-I & Negative & Negative \\
\hline Hand $\mathrm{B}$ - cooking area & Negative & Negative & Negative \\
\hline Hand $\mathrm{B}$ - cooking area & CNF-I & Negative & Negative \\
\hline Hand $\mathrm{B}$ - cooking area & Negative & Negative & Negative \\
\hline Hand $\mathrm{A}-$ pre-preparation and preparation areas & Negative & Negative & Negative \\
\hline Fish—after preparation stage & Negative & Negative & Negative \\
\hline Fish-after preparation stage & Negative & Negative & Negative \\
\hline Shellfish - after reception stage & Negative & Negative & Negative \\
\hline Shellfish-after pre-preparation stage & Negative & Negative & Negative \\
\hline Shellfish-after pre-preparation stage & Negative & Negative & Negative \\
\hline Shellfish-after pre-preparation stage & Negative & Negative & Negative \\
\hline Shellfish-after pre-preparation stage & Negative & Negative & Negative \\
\hline Shellfish-after preparation stage & CNF-I & Negative & Negative \\
\hline Shellfish-after preparation stage & CNF-I & Negative & Negative \\
\hline Shellfish-after preparation stage & Negative & Negative & Negative \\
\hline Shellfish-after preparation stage & CNF-I & Negative & Negative \\
\hline Shellfish-after preparation stage & CNF-I & Negative & Negative \\
\hline Shellfish-after preparation stage & CNF-I & Negative & Negative \\
\hline
\end{tabular}

workshops and training materials should be held for continuous on-the job education of food service employees as well as food service supervisors and managers.

\section{Acknowledgements}

The management and staff of the restaurant involved in the study facilitated and assisted in the collection of samples. CAPES - Brazil study sponsors.

\section{References}

Aiçiçek, H., Aydogan, H., Kuçukkaraaslan, A., Baysallar, M., \& Basustaoglu, A. C. (2004). Assessment of the bacterial contamination on hands of hospital food handlers. Food Control, 15, 253-259.

Bennett, R. W., Nortermans, S., \& Tatini, S. R. (1992). Staphylococcal enterotoxins. In American Public Health Association (Ed.), Compendium of methods for the microbiological examination of foods (3rd ed., pp. 551-592). Washington: APHA.

Blanco, M., Blanco, J. E., Alonso, M. P., Balsanobre, C., Mouriño, M., Madrid, C., et al. (1996). Polymerase chain reaction for detection of Escherichia coli strain producing cytotoxic necrosing factor type 1 and 2 (CNF1 and CNF2). Journal of Microbiological Methods, 26, 95-101.

Blanco, M., Blanco, J. E., Rodríguez, E., Abalia, I., Alonso, M. P., \& Blanco, J. (1997). Detection of virulence genes in uropathogenic Escherichia coli by polymerase chain reaction (PCR); comparison with results obtained using phenotypic methods. Journal of Microbiological Methods, 31, 37-43.

BRASIL (2004). DATASUS-Ministério da Saúde. Informações de saúde. http://tabnet.datasus.gov.br/tabnet/tabnet.htm. (acesso julho 2004).

Brest, P., Turchi, L., Le Negrate, G., Berto, F., Moreilhon, C., Mari, B., et al. (2004). Escherichia coli cytotoxic necrotizing factor 1 inhibits intestinal epithelial wound healing in vitro after mechanical injury. Infection and Immunity, 72, 5733-5740.

Daley, E. F., Pagotto, F., \& Farber, J. M. (1995). The inhibitory properties of various sponges on Listeria spp. Letters in Applied Microbiology, 20, 195-198.

Hitchins, A. D., Hartman, P. A., \& Todd, E. C. D. (1992). ColiformsEscherichia coli and its toxins. In American Public Health Association
(Ed.), Compendium of methods for the microbiological examination of foods (3rd ed., pp. 325-369). Washington: APHA.

ICMSF (International Commission on Microbiological Specification for Foods). (1988). Application of the hazard analysis critical control point (HACCP) system to ensure microbiological safety and quality. In Microorganisms in Foods, 1st ed. 377p.

Innis, M. A., Gelfand, D. H., Sninsky, J. J., \& White, T. J. (1990). PCR protocols: A guide to methods and applications. Academic Press.

Jackson, M. P., Neill, R. J., O’Brien, A. D., Holmes, R. K., \& Newland, J. W. (1987). Nucleotide sequence analysis and comparison of the structural genes for Shiga-like toxin I and Shiga-like toxin II encoded by bacteriophages from Escherchia coli. FEMS Microbiology Letters, 44, 109-114.

Jackson, M. P., Newland, J. W., Holmes, R. K., \& O'Brien, A. D. (1988). Nucleotide sequence analysis of the structural genes for shiga. Microbial Pathogenesis, 2, 147-153.

Kaisner, C. A., Tamplin, M. L., \& Twedt, R. M. (1992). Vibrio. In American Public Health Association (Ed.), Compendium of methods for the microbiological examination of foods (3rd ed., pp. 451-473). Washington: APHA.

Lancette, G. A., \& Tatini, S. R. (1992). Staphylococcus aureus. In American Public Health Association (Ed.), Compendium of methods for the microbiological examination of foods (3rd ed., pp. 533-550). Washington: APHA.

Messer, J. W., Midura, T. F., \& Peeler, J. T. (1992). Sampling plans, sample collection, shipment, and preparation for analysis. In American Public Health Association (Ed.), Compendium of methods for the microbiological examination of foods (3rd ed., pp. 25-49). Washington: APHA.

Meysick, K. C., Mills, M., \& O'Brien, A. D. (2001). Epitope mapping of monoclonal antibodies capable of neutralizing cytotoxic necrotizing factor type 1 of uropathogenic Escherichia coli. Infection and Immunity, 69, 2066-2074.

Ojeniyi, B., Ahrens, P., \& Meyling, A. (1994). Detection of fimbrial and toxin genes in Escherichia coli and their prevalence in piglets with diarrhoea. The application of colony hybridization assay, polymerise chain reaction and phenotypic assays. Journal Veterinary Medicene B, $41,49-59$.

ONU/OMS, Organizacion Mundial de la Salud. (1991). Definiciones y procedimientos generales del HACCP para su uso por el codex. Comission del codex alimentarius. Washington, pp. 11. 
Panisello, P. J., Rooney, R., Quantick, P. C., \& Stanwell-Smith, R. (2000). Application of foodborne disease outbreak data in the development and maintenance of HACCP systems. International Journal of Food Microbiology, 59, 221-234.

So, M., \& McCarty, B. J. (1980). Nucleotide sequence of the bacterial transposon TN1681 encoding a heat-stable (ST) toxin and its identification in enterotoxigenic Escherichia coli strains. Proceedings of the National Academy of Sciences of the United States of America, 77, 4011-4015.

Solberg, M., Buckalew, J. J., Chen, C. M., Schaffner, D. W., O'neill, K., Mcdowell, J., et al. (1990). Microbiological safety assurance system for foodservice facilities. Food Technology, 44, 68-73.
Soriano, J. M., Font, G., Moltó, J. C., \& Mañes, J. (2002). Enterotoxigenic staphylococci and their toxins in restaurant foods. Trends in Food Science and Technology, 13, 60-67.

Stevenson, K. E., \& Segner, W. P. (1992). Mesophilic aerobic sporeformes. In American Public Health Association (Ed.), Compendium of methods for the microbiological examination of foods (3rd ed., pp. 265-289). Washington: APHA

Sveum, W. H., Moberg, L. J., Rude, R. A., \& Frank, J. F. (1992). Microbiological monitoring of the food processing environment. In American Public Health Association (Ed.), Compendium of methods for the microbiological examination of foods (3rd ed., pp. 51-74). Washington: APHA. 